\title{
Some Frontires In Marine Biodiversity Studies
}

\section{JIAO NIANZHI}

Institute of Oceanology. Academia Sinica, Qingdao 266071 (Chena)

(Received May 3)

\section{ABSTRACT}

Some frontiers in marine biodiversity studies are introduced. Nano-and pico-planktons, primary productivity. some ecological porcesses and energy flow pathways. all of which are of crucial importance for our understanding of ecological, eneviroimental and climatic problenıs. are discussed.

Key words marine biodoversity. nano-picoplankton. primary productivity, energy flow pathway

Since the declaration of the Bali Action Plan (1982), preserving biodiversity has become one of the central problems concerned by all countries over the world. Effective action should be taken on the basis of accurate information. However, our knowledge on the exist ing psecies and ecosystems is still very limited, especially in the field of marine biodiversity. With vast area and abundant species, the oceans not only offer great living resources to human beings but also play decisive roles in environmental and climatic changes (SCOR. 1990), and, thus. provide a very important area for biodiversity studies. The objecctivce of this paper is to introuduce some frontiers in marine biodiversity studies with specieal references to the two big problems that must today be confronted by us : living resources and living environments.

\section{Species diversity}

There are more general phyla and more special phyla existing in marine environments than land, fresh water and mutualistic environments. (Vermejj. 1978) and most of the marine species are rarely recorded. It needs to not only go into unusual environments such as deep-sea sediments and hydrothermal vents Grassle, 1985), even in common environments, many species so far as to plylum Loricifora, 1986) have not been discovered. The author, here, will emphasize a more common and familiar class-microplankton, which plays a fundamental role in energy flow in marine ecosystems but is still poorly known by us. Recent studies reveraled that the larger fraction, netplankton ( $>20 \mathrm{um}$ ) known in the past, is 'only a small portion of the total plankton family, and the smaller fractions, nano- $(2 \sim 20$ um $)$ especially picoplanktons ( $<2 \mathrm{um}$ ) which has been ignored before due to the limitation of sample collection and observation methods are more important than netplankton both in biomass and productivity. It seems essentially necessary to recognize the very small species so that we can have a better understanding of marine ecosystems. Studies on nanoplankton have been started in China, and more than 50 species have recored in some representative regions such as Jiaozhou Bay, Xiamen Harbor. There are many new species, e. g. Minidiscus subtilis 
Gao, Cheng et China, 1992; M. ocellatus Gao, Cheng et Chin, 1992; M. spinulosus Gao Cheng et China, 1992; Cymatosira gibberula cheng et Gao, 1993; Rocella marina Cheng et Gao, 1993; Cyclotella cryptica var. ambigua chang, Gao et chin. 1992; Thalassiosira laevis Gao et Cheng, 1992; T. binata var. minor Gao et cheng. 1992: T. binata var. bibinata Gao et cheng, 1992; Chrysochromulina Chiton var. minuta Gao, Tseng et Guo, 1993; C. Papillata Gao. Tseng et Guo, 1993; Paraphysomonas bisorbulina Gao. Tseng et Guo, 1993; and P. simplexocorbita Gao, Tseng et Guo, 1993.

Works on picoplankton is just started. But it is believed that the principal component of picoplanton is cyanobacteria, which is very small in cell size and nearly unsinking. With special ecological properties, these species are particularly important and need more effort to study.

\section{Ecological diversity}

There is no need to discuss the structural and functional differences among marine ecosystems in different latitudes, even in certain environmetns familiar to us. Many ecological processes are never known before. In view of the major problems we are facing today, special attention should be paid to the most common but most dominating ecosystem, the epipelagic ecosystem, for studying the marine material cycling and energy flow.

2. 1 Diversity in the composition of promary production

Firstly, primary producer includes not only eukaryote (mainly, phytoplankton) but also prokaryote (mainly, cyanobacteria), and the latter is a singificant fraction. Preliminary studies in Jiaozhou Bay indicated that the biomass of cyanobacteria ranged from 200 cells $\backslash$ $\mathrm{ml}$ to $10^{4}$ cells $/ \mathrm{ml}$, and its production accounted for $15 \sim 13 \%$ of the total primary production. Secondly, net-, nano-, and picoplankton account for $16 \sim 25 \%, 38 \sim 60 \%$ and $25 \sim$ $45 \%$ respectively of the total biomass, and $11 \sim 30 \%, 35 \sim 53 \%$, and $30 \sim 55 \%$ of the total primary production (Jiao et al., 1993) (1). Thirdly, in the existing state of the products, there are not only the particulate state (the cell its self DOC) but also a substantial part of the production released as dissloved organic carbon (DOC). The proportion of DOC in Jiaozhou Bay ranged from 6.85 to $57.14 \%$ of the total production. In the whole euphotic zone, DOC accounted for $17 \%$ of the total production on an annual base (Jiao \& Wang. 1993). Thus, previous measurement of primary production by $14 \mathrm{C}$ method must have induced serious negative errores. Finally, total primary production can be divided into two parts according to their ecological functions, the new production and the regenerated production (Eppley, 1989). The ratio of new production to the total ranges from $10 \%$ to $80 \%$ owing to the variation of environment conditions.

2. 2 Diersity in the ecological processes and energy flow pathways

Although the importance of biogenic elements $\mathrm{C}, \mathrm{N}, \mathrm{P}$ for primary production has been generally understood, little is known about the diversity of nutrient dynamical processes Taking nitrogen as an example, all forms of nitrogen can be classified as oxidized and reduced nitrogen. Differences in the existing form state if nitrogen affect not only the growth rate but also the composition of primary producer. Recent studies have showed the inhibition of nitrate uptake in the presence of ammonium (Jiao, 1993). Further studies indicated that

(1) Jiao N. Z. et al. . 1993. Size-fractionated characteristics of marine primary production process. (unpublished). 
the smaller the cell size was. the more prefer able for ammonium. and in contrast, nitrate was mainly uptaken by larger cells (Jiao, 1993 unpublished). This phenomenon means that, for a given nitrogen-limited region, changing the proportion of reduced nitrogen to ox idized nitrogen would change the composition of the size structure, and then might change the structure of food chain. If it is supplied mainly by reduced nitrogen. the smaller cells would ultimately win in interspecific competition. This means that more energy would cycle within the lower trophic levels, and thus. the function of the ecosystem would smoewhat be reduced. This is a sensitve ecological problem and needs thorough studies to aseertain. An other important concept related to nutrient diversity is new production which is technically the fraction of primary prouction supported by oxidized nitrogen (in pelagic ecosystem). New production is not only a functionl index of ecosystem. but also a measurement of net carbon flux from the air to the ocean. and therefore an estimation of the capability of the 0 cean to regulate climate changes (SCOR, 1990). The level of new production is affected by many factors including the composition and proportion of nitrogen sources, planktonic organisms, and size structure of primary producer etc. Generally. new production is lower in pelagic waters than in coastal waters .

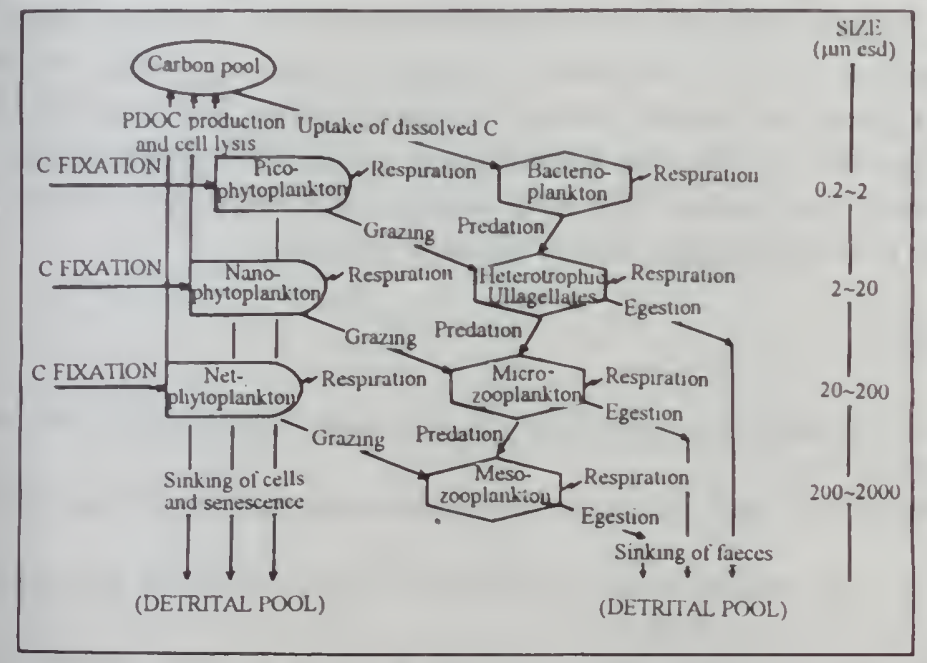

Fig. Pathways of energy flow in plankon community (after Moloney \& Field, 1991)

Recent achievment in marine food we strudies indicates that the energy flow pathway is very complicated and the outline we described in the past is so rough and simple that a great of valuable information has been ignored. For example. from primary producer to secondary, there are different pathways for energy flow (Fig. ), and different pathways have different efficiencies. A portion of energy from netphytoplankton production may preserve more that $10 \%$ when it reaches the trophic level of mesozooplankton. While the same portion of energy contributed by picoplankton, perhaps, remains only $1 \%$ when it reaches the same trophic level. This tells us the importance of invertigating the process diversity for the understanding of ecosystem functions

The photosynthetically produced DOC is not gone forever. A substantial portion of DOC will be taken up by free-living heterotrophic bacteria and transformed into the DOC pool again. Traditional ideas take heterotrophic bacteria as decomposer, but in view of these 
facts, they are also a producer. These DOC formed by bacteria can not be grazed directly by metazoon due to their extremely small size, but can only be transferred by protozoon (Fig. ). This forms a DOC -bacteria-protozoon food chain called microbial food loop (Azam et al., 1983), establishing the third food chain model besides the tow typical models, the grazing food chain and the detritus food chain. Investigation results show that the contribution of bacteria to marine ecosystem is undoubtedly important. In oligotrophic oceans, bacterial biomass is $2 \sim 3$ times greater than phytoplankton, and accounts for $26 \sim 62 \%$ of the total DOC (Cho et al., 1990). The secondary productivity of backeria is up to $71 \sim 726 \mathrm{mg}$ m3. d (Fuhrman et al., 1980; wheeler et al., 1986).

\section{Summary}

Marine biodiversity is a new area for studying nutrient cycling and energy transfer in the oceans and our knowledge about it is still very limited. The development of society needs to develop and utilize the ocean. Among numerous urgent works including preserving the developed economical species, an important aspect is to understand the structure and function of marine ecosystems and the role of biodiversity it from the basic links. We can utilize the ocean scientifically only on the basis of a comprehensive knowledge. The basic links are just the decisive points for material cycling and energy flow. Those aspects discussed above are not only important but also the breakthrough points for understanding marine ecosystems in a relatively short period. We have already had a stepping stone and we will make further progress in marine biodiversity in the near future.

\section{REFERENCES}

Azam F, Fuhrman J A, 1983. The ecological role of water column microbes in the sea. Mar. Ecol. Prog. Ser., 10: $257 \sim 263$

Baker A N. Loricifora E G, 1986. A new class of Echinodermata from New Zealnad. Nature, 321 : 862 864

Cho B C, Azam F, 1990. Biogeochemical singificance of bacterial biomass in the ocean's euphoric zone. Mar. Ecol. Prog. Ser., 63:253 257

Eppley R W, 1989. New production: history, methods. problems. in: Productivity of the Ocean: Present and Past. Berger W H, John Wiley. Sons Limited (N.Y.) eds. 85 97

Fuhrman J A, Azam F, 1980. Bacteria plankton secondary production estimates for coastal waters of British Columbia, Antarctica and California, Appl. Environ. Microbio., 39(6): 1085 1095

Gao Yu. 1993. Some new species of nanoplankton in Jiaozhou Bay. In: Liu R ed, Ecology and Living resources of Jiaozhou Bay. Academia Press. 203 219

Gao Yahui. Cheng Zhaodi, 1992. A new species and two new varieties of Thalassionsira. , J. Xiamen U. . 31(3): $291 \sim 294$

Gao Yahui, Cheng Zhaodi, 1992. Tro new species of Minidiscus and a new variety of Cyclotella. J. Xiamen $U$.. 31(1): $74 \sim 77$

Grassle J F. 1985. Hydrothermal vent animals: Distribution and biology. Science. , 229: 713 717

Jiao N Z. Wang R. 1993. Light-dependences of size-fractionated photosynthesis and PDOC release of natural phytoplankton assemblages. Proceedings of INMBSCS (Guangzhou China), 45

Jiao N Z, 1993. Interactions between ammonium and nitrate uptake by natural microplankton assemblages. Chinese J. Oceanol. Limnol., 11(2): 97 108

Moloney C L. Field J G. 1991. The size-based dynamics of plankton food webs. J. Plankton Res. , 13 
直接copy本文内容时会有误差，请注意核对！

(5): $1003 \sim 1038$

SCOR. 1990. JGOFS science plan. JGOFS Report, 5:1 51

Vermejj G J. 1978. Biogeography and adaption: Patterns of Marine life. Hurzurd C'meersty P'ress. Cambridge, MA.

Wheeler P A. Kirchman D) L. 1986. Utilization of inorganic and organic nitrogen by bacteria in marine systems. Limmol. Oceanogr.. 31(5): 998 1009 